\title{
A double-blind, placebo controlled, multicentre study of the efficacy and safety of 5-aminosalicylic acid tablets in the treatment of ulcerative colitis
}

\author{
LR SUTHERLAND, MD, M ROBINSON, MD, G ONSTAD, MD, M PEPPERCORN, MD, \\ N GREENBERGER, MD, M GOODMAN, MD, F MARTIN, MD
}

\begin{abstract}
This double-blind, placebo controlled, multicentre, parallel trial assessed the efficacy of two oral doses of a new formulation of 5-aminosalicylic acid (5-ASA) targeted to release in the cecum which was given for six weeks to 136 patients with active ulcerative colitis. Seven centres participated (two Canadian, five American). Patients were randomly assigned to one of three treatment groups (4 g 5-ASA, 2 g 5-ASA or placebo). Medication was dispensed as $250 \mathrm{mg}$ identically appearing tablets containing either 5-ASA or placebo to be taken four times a day. Subjects were assessed at baseline and after three and six weeks of treatment. Assessments included a disease activity index, physician's global assessment and flexible sigmoidoscopy. Compliance was assessed through pill count. A total of 136 patients participated ( 47 on $4 \mathrm{~g} 5$-ASA, 45 on $2 \mathrm{~g} 5$-ASA, and 44 on placebo). The three groups were similar in terms of age, weight, distribution of disease, extent of disease, and previous use of steroids or sulphasalazine. Ninety patients completed the six week study. Of the 46 dropouts, $38(82.6 \%$ ) left because of insufficient efficacy (most on either placebo or $2 \mathrm{~g} 5$-ASA), four ( $8.7 \%$ ) had adverse reactions (all on 5-ASA), the remaining four $(8.7 \%)$ left for reasons not related to their ulcerative colitis. The disease activity index represents a composite score (maximum of 12 ) with categories for number of daily stools, presence of bleeding, abdominal pain and physician's assessment of disease activity. Patients who received $4 \mathrm{~g}$ 5-ASA daily demonstrated significant declines in disease activity index within three weeks of therapy and maintained improvement until the end of the study. Although disease activity index declined for patients receiving $2 \mathrm{~g} 5$-ASA daily, these changes did not reach statistical significance when compared to placebo-treated patients. On a five point scale (much improved, somewhat improved, unchanged, somewhat worse, much worse) the physician's global assessment mirrored the changes in disease activity index. Patients randomized to receive $4 \mathrm{~g} 5$-ASA tablets were consistently noted as being either much or somewhat improved compared to placebo-treated patients. Side effects were few and minor and
\end{abstract}

University of Calgary, Calgary, Alberta; University of Oklahoma, Oklahoma City, Oklahoma, USA; Hennepin County Medical Centre, Minneapolis, Minnesota, USA; Harvard University, Boston, Massachusetts, USA; University of Kansas, Kansas City, Kansas, USA; Chattanooga, Tennessee, USA; University of Montreal, Montreal, Quebec

Correspondence and reprints: Dr LR Sutherland, Room 1717, 3330 Hospital Drive NW, Calgary, Alberta T2N 4N1. Telephone (403) 220-4500
$\mathrm{T}$ HE DEMONSTRATION BY AZAD Khan (1) and others (2) that 5 aminosalicylic acid (5-ASA) was the active ingredient of sulphasalazine, followed by the development of the first targeted delivery system by Dew and colleagues (3), has opened up a new therapeutic option for the treatment of inflammatory bowel disease. Many of the newer preparations consist of an inner core of 5-ASA, surrounded by an envelope of resin which will dissolve at different pHs. Rowasa (Reid-Rowell, Georgia) is such a compound which is targeted to release 5-ASA in the distal terminal ileum and cecum. Its release profile has recently been published (4), and in ileostomates approximately $80 \%$ of the total 5-ASA given can be recovered either as 5-ASA or its metabolite, n-acetyl-5-ASA, in either the ileostomy effluent or urine. To date there has appeared to be some controversy as to the appropriate daily dose of 5-ASA required to induce remission in patients with ulcerative colitis. The results of a dose finding study of 5-ASA in patients with active ulcerative colitis is reported.

\section{PATIENTS AND METHODS}

This multicentre, double-blind parallel design study assessed the safety and efficacy of two doses of Rowasa (2 
$52 \%$ (4 g 5-ASA), 42\% ( 2 g 5-ASA) and $37 \%$ (placebo) of patients had no complaints. Headache was the most commonly cited adverse reaction for $6.9 \%$ ( $4 \mathrm{~g} \mathrm{5-ASA})$ and $9.4 \%(2 \mathrm{~g} 5$-ASA) of treated patients but $3.5 \%$ of placebotreated patients also complained of headache. In conclusion in this randomized double-blind, placebo controlled study, patients with active ulcerative colitis randomized to $4 \mathrm{~g}$ 5-ASA per day noted improvement in disease activity as measured by disease activity index and physician's global assessment when compared to placebo-treated patients. In contrast, patients who received $2 \mathrm{~g}$ 5-ASA daily did not demonstrate significant differences compared to the placebo group. Can J Gastroenterol 1990;4(7):463-467

\section{Key Words: 5-aminosalicylic acid, Clinical trial, Ulcerative colitis}

\section{Essai multicentrique contrôlé à double insu contre placebo portant sur l'efficacité et l'innocuité des comprimés d'acide 5-aminosalicylique dans le traitement de la colite ulcéreuse}

RESUME: L'auteur fait état d'un essai parallèle multicentrique à double insu contre placebo visant à évaluer l'efficacité de deux prises orales d'un nouveau médicament à base d'acide 5-aminosalicylique agissant au niveau du caecum. Dans les sept centres participants - deux au Canada et cinq aux E. U., le médicament ou le placebo ont été administrés pendant six semaines à 36 patents porteurs de colite ulcéreuse. Il était dispensé en quatre prises quotidiennes, sous forme de comprimés de $250 \mathrm{mg}$ et d'aspect identique contenant soit du 5-ASA $(4 \mathrm{~g}, 2 \mathrm{~g})$ soit un placebo. Les sujets ont été évalués à l'état basal et après trois et six semaines de traitement, selon l'index d'activité de la maladie [DAII], le bilan général et la sigmoïdoscopie flexible. L'adhésion du patient au traitement était déterminée d'après le nombre de comprimés. Les 136 sujets étaient répartis en trois groupes: 47 sous $4 \mathrm{~g}$ de 5 -ASA; 45 sous $2 \mathrm{~g}$ de 5 -ASA et 44 sous placebo. Les trois groupes étaient similiaires quant à l'âge et au poids des patients, à la distribution et à l'étendue de la maladie, et à l'utilisation passée de stéroïdes ou de sulfasalazine. Quatre-vingt-dix patients ont terminé cette étude de six semaines et 46 l'ont interrompue. Trente-huit personnes $(82,6 \%)$ ont cessé le traitement à cause de son inefficacité (la plupart était sous placebo ou sous $2 \mathrm{~g}$ de 5-ASA), quatre d'entre elles $(8,7 \%)$ souffraient d'effets indésirables (toutes sous 5 - ASA) et les autres ont abandonné le traitement pour des raisons étrangères à leur condition. Le DAI représente un score composite ( 12 maximum) et se compose de catégories mesurant le nombre quotidien de selles, la présence de saignement, la douleur abdominale et l'évaluation de l'activité de la malade par le médecin. On relève une basse significative du DAI en trois semaines de traitement chez les patients qui ont reçu $4 \mathrm{~g}$ de 5 -ASA par jour et ces résultats se sont maintenus jusqu'à la conclusion de l'essai. Bien que le DAI ait diminué chez les patents recevant $2 \mathrm{~g}$ de 5 -ASA/jour, les changements n'ont pas atteint le seuil de significativité par rapport aux patients sous placebo. Sur une échelle de cinq points (amélioration considérable, amélioration moyenne, aucun changement, détérioration moyenne, détérioration grave), le bilan général du médecin reflétait les changements du DAI. De façon constante, les chercheurs ont relevé des améliorations considérables ou moyennes chez les patients randomisés et recevant $4 \mathrm{~g}$ de 5 -ASA, par rapport au groupe pacebo. Les effets secondaires étaient rares et mineurs: $52 \%$ ( $4 \mathrm{~g}$ de 5-ASA, $42 \%$ ( $2 \mathrm{~g}$ de 5-ASA) et $37 \%$ (pacebo) n'en ont rapporté aucun. Les céphalées constituaient l'effet indésirable le plus fréquent chez $6,9 \%$ ( $4 \mathrm{~g}$ de 5 -ASA) et $9,4 \%$ ( $2 \mathrm{~g}$ de 5 -ASA) des patients sous 5 -ASA mais 3,5\% des sujets recevant un placebo ont rapporté le même problème. En conclusion, dans cet essai randomisé à double insu contrôlé contre placebo, les patients porteurs de colite ulcéreuse en évolution ayant reçu $4 \mathrm{~g}$ de 5-ASA par jour ont manifesté une amélioration de l'activité de la maladie mesurée selon le DAI et le bilan général du médecin, par rapport au groupe placebo. Par contre, les patients à qui on a administré $2 \mathrm{~g}$ de 5 -ASA n'ont manifesté aucune différence significative. or $4 \mathrm{~g}$ daily) compared to placebo in 136 patients with ulcerative colitis of variable extent. Seven centres participated (five American, two Canadian) with all patients enrolled between July 1985 and September 1986. The protocol received ethical approval by each participating institution's ethical review board. All patients gave in. formed consent prior to study entry.

To be included patients had to be at least 18 years of age with active ulcerative colitis extending at least $20 \mathrm{~cm}$ proximal to the anus. Males and nonpregnant females were eligible. As well, patients had to have a minimum score of 4 measured by the disease activity index (5), which consists of four subscales for bowel frequency, presence of blood, sigmoidoscopic appearance and physician's assessment of severity, for a maximum score of 12 . Patients with Crohn's disease, infectious colitis, salicylate allergy or clinically significant hepatic, renal or cardiovascular disease were excluded.

Prior to entry patients were screened with a baseline history, physical and flexible sigmoidoscopy or colonoscopy. If a colonoscopy had been performed within the past year, the extent of disease was considered to have been determined by that procedure. The disease activity index was calculated. Lab. oratory assessments including stool culture were performed. Patients were randomly assigned to receive either 250 mg tablets of Rowasa or identically ap. pearing placebos taken as four tablets, four times per day. All assignments to treatment and subsequent assessments of response to treatment were under double-blind conditions.

Patients were assessed by telephone contact at the end of weeks 1,2,4 and 5 and were examined in the clinic at the end of weeks 3 and 6 . At each clinic visit repeat flexible sigmoidoscopy was performed, a physician's global assessment determined and a $24 \mathrm{~h}$ urine and plasma sample obtained for drug assay. Any patient whose condition had deteriorated significantly at week 3 was withdrawn and offered the opportunity to participate in an open label study. Statistical analysis: The primary measure of efficacy was change in the 
TABLE I

Demographic characteristics of patients in a double-blind, placebo controlled multicentre study of 5-aminosalicylic acid (5-ASA) in ulcerative colitis

\begin{tabular}{llll}
\hline & 4 g 5-ASA & 2 g 5-ASA & Placebo \\
\hline Number enrolled & 47 & 45 & 44 \\
Number completed & 38 & 23 & 24 \\
Sex (male/female) & $26 / 21$ & $31 / 14$ & $18 / 26^{\circ}$ \\
Age (years) (mean \pm SD) & $39.1 \pm 12.0$ & $39.1 \pm 12.9$ & $37.8 \pm 12.6$ \\
Pancolitis & $12(26 \%)$ & $5(11 \%)$ & $9(20 \%)$ \\
Left-sided ulcerative colitis & $17(36 \%)$ & $22(49 \%)$ & $18(41 \%)$ \\
Proctosigmoiditis & $18(38 \%)$ & $18(40 \%)$ & $17(39 \%)$ \\
Upper disease boundary $(\mathrm{cm})$ & $43.5 \pm 14.8$ & $46.7 \pm 15.5$ & $41.0 \pm 13.6$ \\
Prior use of steroids & 33 & 33 & 33 \\
Prior use of sulphasalazine & 44 & 40 & 39 \\
\hline
\end{tabular}

-Significant group difference at the $5 \%$ level

disease activity index score (end of study minus baseline). A fixed effects analysis of variance (ANOVA) was used to assess treatment and centre differences as well as the homogeneity of treatment effect across centres. Statistical significance for the main effects due to treatments and centres were judged at the $5 \%$ level.

The null hypothesis was that, on average, the improvement in the 5 . ASA group was less than or equal to that in the placebo group. The results from these analyses were confirmed through the use of nonparametric testing. Statistical significance was judged at the $5 \%$ level.

No formal statistical method was used to derive the total sample size prior to onset of the study. However, if change in disease activity index is used as the endpoint, the power of the F test to detect treatment differences of the size observed in the study is greater than $80 \%$.

\section{RESULTS}

One hundred and thirty-six patients were enrolled; 46 (33.8\%) were unable to complete the six week study. The number of patients entered at each centre ranged from nine to 31 . Characteristics of the three study groups are presented in Table 1. The three treatment groups were comparable in terms of mean age, distribution of disease and mean upper disease boundary. Most patients gave a past history of both steroid and sulphasalazine use. More women were randomized to the placebo group than to the active treatment groups. Mean disease activity indices for all groups were similar.

The majority of dropouts occurred in the first three weeks of the study. Insufficient efficacy was the most commonly cited reason for withdrawal. Significantly fewer dropouts for lack of efficacy were noted in the $4 \mathrm{~g} 5$-ASA per day group compared to the $2 \mathrm{~g}$ per day and placebo-treated groups. Three of four patients (all on 5-ASA), who withdrew because of adverse experiences, did so because of diarrhea.

At three weeks, disease activity measured by percentage decline in mean disease activity index had declined significantly for patients randomized to 4 g 5-ASA per day (-29.6\%)
TABLE 2

Mean disease activity index scores by treatment group and time of patients from a double-blind, placebo controlled multicentre study of 5-aminosalicylic acid (5ASA) treatment for ulcerative colitis

\begin{tabular}{lccc}
\hline & $\mathbf{4 g}$ & $\mathbf{2 ~ g}$ & Placebo \\
& 5-ASA & 5-ASA & \\
\hline Baseline & $8.5 \pm 2.3$ & $9.0 \pm 2.2$ & $8.2 \pm 1.9$ \\
3 weeks & $5.9 \pm 3.1^{*}$ & $7.8 \pm 3.8$ & $7.8 \pm 2.9$ \\
6 weeks & $4.0 \pm 3.5^{*}$ & $6.4 \pm 3.9$ & $6.0 \pm 3.7$ \\
Endpoint & $4.8 \pm 3.9^{*}$ & $7.7 \pm 4.0$ & $7.7 \pm 3.6$ \\
\hline "4 g versus placebo, P<0.05. ANOVA
\end{tabular}

compared to those on placebo ( $3.1 \%$ by ANOVA, $\mathrm{P}<0.05$ ) (Table 2, Figure 1). Improvements in the subscales of the disease activity index were noted in reduction of rectal bleeding, sigmoidoscopic appearance and physician's assessment.

Continued improvement compared to baseline was noted at six weeks $(-52.1 \%$ with $4 \mathrm{~g}$ per day versus $-21.2 \%$ with placebo, ANOVA, $\mathrm{P}<0.05$ ). This improvement in disease activity index score was parallelled by the 'Physicians's Overall Assessment', in which more $4 \mathrm{~g}$ patients were characterized as either 'much improved' or 'somewhat improved' compared to those receiving placebo $(63.1 \%$ versus $27.9 \%, \mathrm{P}<0.001$ ) (Table 3 ).

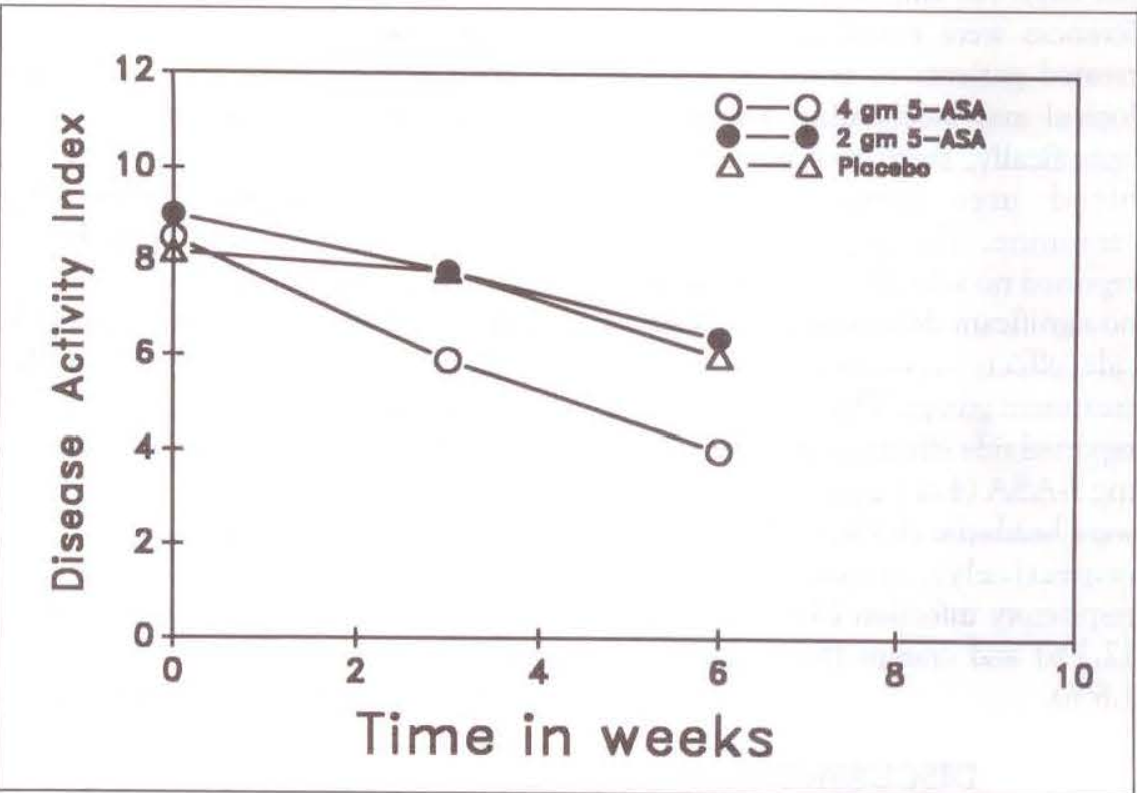

Figure 1) Decline in disease activity index over time by treatment group. At three and six weeks, significant differences can be detected between the $4 \mathrm{~g}$ 5-aminosalicylic acid (5-ASA)-treated patients and placebo-treated patients 


\section{TABLE 3}

Physician's Overall Assessment at endpoint of double-blind, placebo controlled multicentre study of 5-aminosalicylic acid (5-ASA) treatment for ulcerative colitis

\begin{tabular}{lccc}
\hline & $4 \mathrm{~g} 5-$ ASA $^{*}$ & $2 \mathrm{~g} 5$-ASA & Placebo \\
\hline $\begin{array}{l}\text { Much improved or } \\
\text { somewhat improved }\end{array}$ & $64.4 \%$ & $37.8 \%$ & $23.3 \%$ \\
$\begin{array}{l}\text { Unchanged } \\
\text { Somewhat worse or }\end{array}$ & $15.6 \%$ & $28.9 \%$ & $25.6 \%$ \\
$\quad$ much worse & $20.0 \%$ & $33.3 \%$ & $51.1 \%$ \\
\hline
\end{tabular}

Study endpoint refers to patient status either at study conclusion (six weeks) or at time of withdrawa from study. "Significant at $P<0.001$

Although patients in the $2 \mathrm{~g}$ per day treatment group demonstrated some improvement in disease activity index scores, these changes were not significant when compared to the entry disease activity index. Similarly, the Physician's Overall Assessment for $2 \mathrm{~g}$ 5-ASA-treated patients showed some improvement in status, but the changes were not statistically significant compared to placebo. It is of interest to note that approximately $23 \%$ of placebotreated patients were considered by their physicians to be either much or somewhat improved.

Compliance and adverse effects: There were nô differences in compliance between treatment groups measured by pill counts. The lowest mean tablet intake per day was 14.9 , suggesting good compliance (expected intake 16 tablets per day). No clinically significant differences were noted among 5-ASAtreated patients in terms of hematological and biochemical assessments. Specifically, there was no change in blood urea nitrogen or serum creatinine. The majority of patients reported no side effects and there were no significant differences in numbers of side effects reported by the various treatment groups. The most commonly reported side effects for patients receiving 5-ASA ( 4 or $2 \mathrm{~g}$ per day) or placebo were headache $(6.9 \%, 9.4 \%$ and $5.3 \%$, respectively), symptoms of upper respiratory infection $(3.4 \%, 4.7 \%$ and $12.3 \%)$ and cramps $(5.2 \%, 1.6 \%$ and $1.8 \%)$.

\section{DISCUSSION}

The mechanism of action of 5-ASA is unknown. Possible therapeutic actions include modulation of the inflam- matory response through effects on leukotriene synthesis $(6,7)$ rather than through effects on prostaglandin synthesis (8). Recently evidence has been presented suggesting that 5 -ASA is an effective free radical scavenger and that it breaks the free radical chain reaction (9).

A variety of 5-ASA-containing oral preparations are available for use in patients with ulcerative colitis $(6,10)$. While it may be convenient to describe each compound as 5-ASA, differences in the delivery systems suggest that physicians will have to be aware of proprietary rather than generic identifiers.

To date there appear to be some differences of opinion as to the appropriate daily dose. Originally it was thought that the substitution of 5-ASA for equimolar amounts of sulphasalazine would suffice, but recent reports have questioned this. Schroeder and colleagues (11) assessed a 5-ASA preparation timed to release in the colon (Asacol; Norwich-Eaton, $4.8 \mathrm{~g}$ 5-ASA, $1.6 \mathrm{~g}$ 5-ASA, and placebo) in 87 patients with mildly to moderately active ulcerative colitis, and were able to demonstrate efficacy only at the $4.8 \mathrm{~g}$ per day dose. The dose of Asacol given was considered equivalent to $12 \mathrm{~g}$ of sulphasalazine.

A second study (12) compared sulphasalazine $2 \mathrm{~g}$ per day with $800 \mathrm{mg}$ and $2.4 \mathrm{~g}$ of Asacol in 61 patients with mildly to moderately active ulcerative colitis. The authors concluded that all regimens were effective but that there was evidence of a trend towards greater efficacy with the $2.4 \mathrm{~g}$ per day schedule.

Azodisalicylate (olsalazine, Dipentum; Pharmacia) contains two 5-ASA molecules which are released by bac. terial action in the large intestine. In a comparison of 37 patients in the midst of their first attack of ulcerative colitis (13), $2 \mathrm{~g}$ azodisalicylate was found to be clinically equivalent to $3 \mathrm{~g}$ sulphasalazine. In this study the equivalent dose of sulphasalazine for $2 \mathrm{~g}$ azodisalicylate would have been $4.6 \mathrm{~g}$ per day.

Trials of a microsphere preparation of 5-ASA (Pentasa; Nordic) have been reported in abstract form. Hanauer (14) reported the results of a multicentre, dose finding study of $1 \mathrm{~g}, 2 \mathrm{~g}$ and $4 \mathrm{~g}$ Pentasa compared to placebo in 374 patients with active ulcerative colitis and found significant improvements in patients randomized to the 2 and $4 \mathrm{~g}$ groups compared to those receiving placebo.

This study is one of the first dose finding evaluations of an entericcoated formulation designed to dissolve in the terminal ileum and large intes. tine. Patients randomized to receive the higher dose of 5-ASA noted sig. nificant improvements compared to those receiving placebo. Additional improvement in disease activity index score continued from the evaluation performed at three weeks compared to that at six. It is possible that further improvements in disease activity index score would have been detected if the trial had continued for a further three weeks. The medication was well tolerated, although a small percentage of patients withdrew because of diarrhea.

This study had a relatively high dropout rate, with one-third of patients (46 of 136) withdrawing before the completion of the study. In the Mayo Clinic study (11), approximately one. quarter of the study population withdrew, mainly because of worsening disease or lack of improvement. Placebo controlled studies have a valu. able role to play in the assessment of any therapy, but frequent dropouts can be anticipated as the treating physician or patient faced with lack of clinical improvement tends to assume that the patient was randomized to placebo.

Rowasa appears to be a safe and ef. fective agent for the therapy of ulcerative colitis. Further studies are required 
to determine the optimal duration of therapy, as well as to examine if additional benefit can be obtained from using even higher doses. Studies comparing efficacy and side effect profiles between not only the new 5-ASA products but also sulphasalazine are warranted.

\section{REFERENCES}

1. Azad Khan AK, Piris J, Truelove SC. An experiment to determine the active therapeutic moiety of sulphasalazine. Lancet 1977;ii:892-5.

2. Van Hees PAM, Bakker JH, Van Tongeren JHM. Effect of sulphapyridine, 5 -aminosalicylic acid, and placebo in patients with idiopathic proctitis: A study to determine the active therapeutic moiety of sulphasalazine. Gut 1980;21:632-5.

3. Dew MJ, Harries AD, Evans BK, Rhodes ]. Treatment of ulcerative colitis with oral 5-aminosalicylic acid in patients able to take sulphasalazine. Lancet 1983;ii:801.

4. McLeod RS, Cohen Z, Vari BJ, Blair
JE, Greenberg GR. The release profile of a controlled release preparation of 5-aminosalicylic acid (Rowasa 1) in humans. Dis Colon Rectum 1990;33:21-5.

5. Sutherland LR, Martin F, Greer $S$, et al. 5-Aminosalicylic acid enema in the treatment of distal ulcerative colitis, proctosigmoiditis, and proctitis. Gastroenterology 1987;92:1894-8.

6. Peskar BM, Dreyling KW, May B, Schaarschmidt K, Goebell H. Possible mode of action of 5-aminosalicylic acid. Dig Dis Sci 1987;32:51S-6S.

7. Lauritsen K, Laursen L, Bukhave K, Rask-Madsen J. Effects of topical 5 aminosalicylic acid and prednisolone on prostaglandin $E_{2}$ and leukotriene $B_{4}$ levels determined by equilibrium in vivo dialysis of rectum in relapsing ulcerative colitis. Gastroenterology 1986;91:837-44.

8. Hawkey CJ. Salicylates for the sulfa-sensitive patient with ulcerative colitis? Gastroenterology 1986;90:1082-4.

9. Ahnfelt-Ronne I, Nielsen OH, Christensen A, Langholz E, Binder V, Reis P. Clinical evidence supporting the radical scavenger mechanism of 5 . aminosalicylic acid. Gastroenterology
1990;198:1162-9.

10. Broaden RN, Sorkin EM. Mesalazine: A review of its pharmacodynamic and pharmacokinetic properties, and therapeutic potential in chronic inflammatory bowel disease. Drugs 1989;38:500-23.

11. Schroeder KW, Tremaine WJ, Ilstrup DM. Coated oral 5-aminosalicylic acid therapy for mildly to moderately active ulcerative colitis. N Engl J Med 1987;317:1625-9.

12. Riley SA, Mani V, Goodman MJ, Herd ME, Duft S, Turnberg LA. Comparison of delayed release 5 . aminosalicylic acid (mesalazine) and sulphasalazine in the treatment of mild to moderate ulcerative colitis relapse. Gut 1988;29:669-74

13. Rao SSC, Dundas SAC, Holdsworth CD, Cann PA, Palmer KR, Corbett CL. Olsalazine or sulphasalazine in first attacks of ulcerative colitis? A double blind study. Gut 1989;30:675-9.

14. Hanauer SB, Schwartz J, Roufail W, et al. Dose-ranging study of oral mesalamine capsule (Pentasa ${ }^{\circledR}$ ) for active ulcerative colitis. Gastroenterology 1989;96:A195. (Abst) 


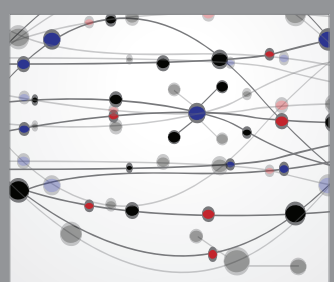

The Scientific World Journal
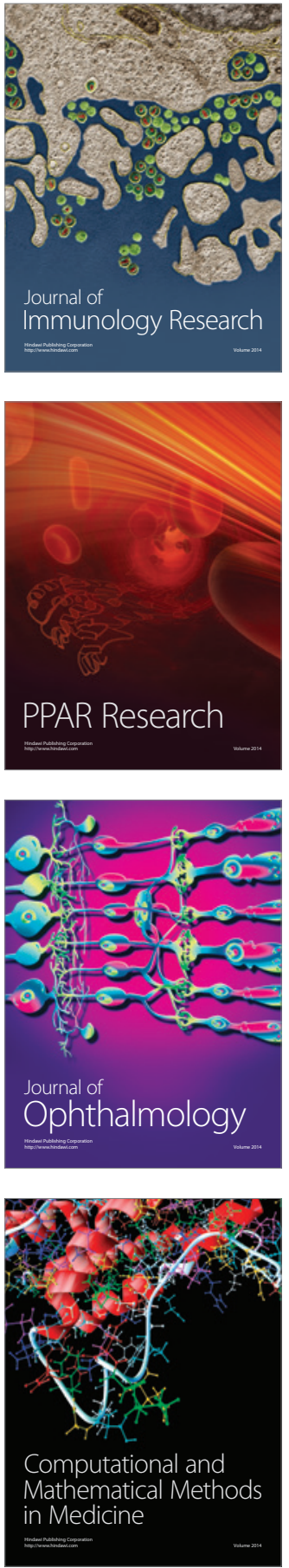

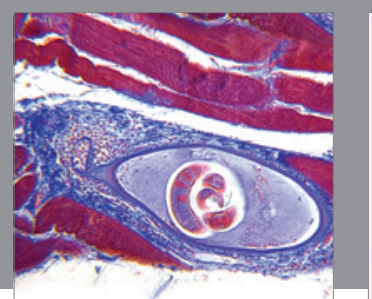

Gastroenterology Research and Practice

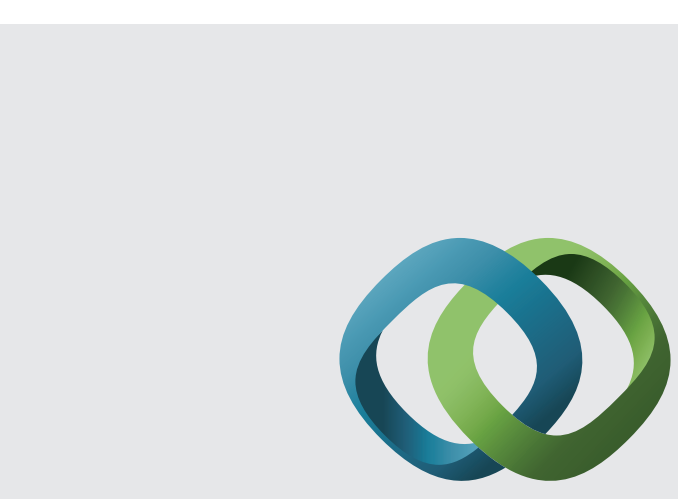

\section{Hindawi}

Submit your manuscripts at

http://www.hindawi.com
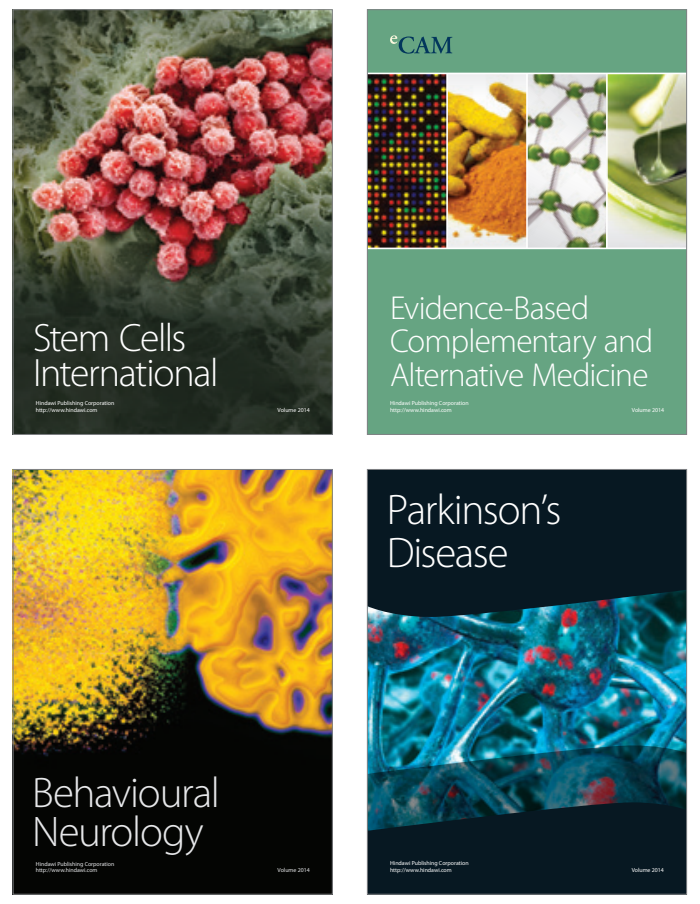
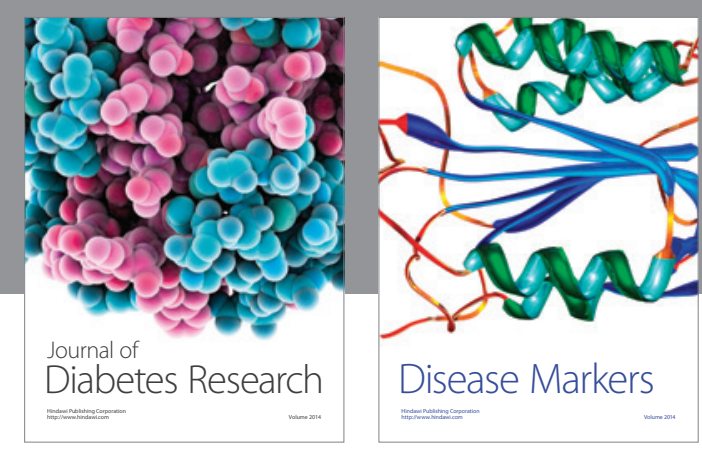

Disease Markers
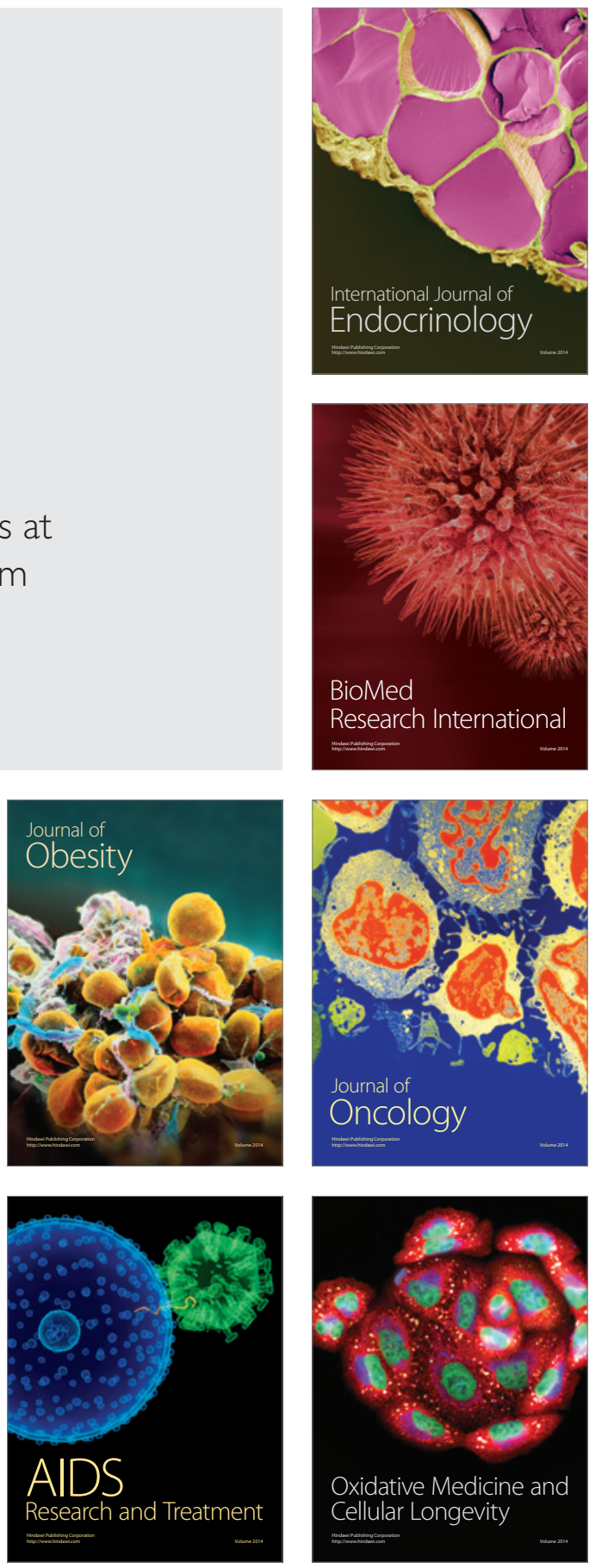